\title{
Decisions for Stock Investment among University Students
}

\author{
Dewi Pertiwi*, Sautma Ronni Basana, and Marcella Grace Yasinta \\ Department of Management, Faculty of Business and Economics, Petra Christian University, \\ Jl. Siwalankerto 121-131, Surabaya 60236, Indonesia
}

\begin{abstract}
This study aimed to investigate the effect of economic value added and profitability on created shareholders value Fernandez model and market value added model in manufacturing companies listed on the Indonesia Stock Exchange period year 2013 to 2018. The samples are fifty Manufacturing companies enterprises listed on the IDX period year 2013 to 2018. Methods of data analysis was performed using panel data regression with pooled OLS model. The results of this analysis showed profitability have a significant effect on created shareholders value Fernandez model and market value added model in manufacturing companies listed on the IDX period 2013 to 2018.
\end{abstract}

Keywords: Created shareholders value, economic value added, fernandez model, manufacturing, market value added model, profitability.

\section{Introduction}

Uncertainty drives individuals to prepare for their future. Investment is one way to prepare for the financial future. Investment is defined as the commitment of current financial resources in order to achieve higher gains in the future [1]. Benefits obtained by investing in the future, for example, to prepare for retirement, to prepare children's education funds, to start a business, and can be used in an emergency [2]. According to the Indonesia Investment Coordinating Board, the realization of Indonesia's investments in 2012 to 2017 was respectively IDR $313 \times 10^{12}$, IDR $399 \times 10^{12}$, IDR $463 \times 10^{12}$, IDR $545 \times 10^{12}$, IDR $613 \times 10^{12}$ and IDR $678 \times 10^{12}$ [3]. From these data, it can be seen that investment activities in Indonesia have increased every year. In addition, the Indonesia Stock Exchange (BEI) stated that as many as $30 \%$ of new investors in 2016 were from students. This makes the IDX continue to hold an investment gallery program [4]. The Indonesia Stock Exchange (IDX) as the manager of securities sales in Indonesia continues to make efforts to increase public investment in the capital market. One of them is by changing the unit of stock purchase, which is usually a minimum purchase of 1 lot is 500 shares now become only 100 shares [5].

Socialization and education programs regarding investing in the capital market also continue to be carried out, especially to academics on campus. Students are of particular concern in the IDX capital market education program, because students are a generation group that is considered capable of developing the capital market industry, with this

* Corresponding author: dewi.pertiwi@petra.ac.id 
socialization and education event, students are expected to be able to become investors in the capital market and disseminate information about these investment instruments to the community [6]. To attract investors among students, parties from the IDX have also opened investment galleries in 107 campuses throughout Indonesia [7]. IDX has also hooked more than 5000 new investors with the "Let's Save Stock" program. Students from several universities participating in the program have regularly bought shares in accordance with the program, so that the number of investors among students is fairly large [8].

Investment is something that must be considered by a student, because the funds invested will increase over time, investment also helps students to meet short-term and long-term goals [9]. In addition, students can invest easily and cheaply, the student can open a stock account just only spending one hundred thousand rupiahs. This can increase the interest of students, especially students with a concentration in financial management because financial management students have knowledge about investment through financial courses that are followed such as capital markets and investment management and portfolios. In addition, financial management students have been equipped with the ability to invest by simulating stock trading. Research conducted by Candiasa et al., [10], states that students who have financial knowledge understand better in seeing the benefits and risks in investment decisions.

In making investment decisions, many factors are considered by investors. According to Heshmat [11], stock investment decisions are influenced by several factors, namely demographic factors, risk tolerance, objective factors, information source factors, market factors, company factors, and stock fundamental factors. The first factor is the demographic factor. Demographic factors in this study use gender, age, and income. In addition, Geetha and Vimala [12] research stated that high income could influence someone in investing, where individuals who have high income are more willing to invest in high-risk investments with the hope of getting high returns as well. In the demographic factors in this study do not use education because the object under study is a student of financial management who took a bachelor degree, so that their investment abilities and knowledge are considered at the same level.

The second factor is the risk tolerance factor. Risk tolerance affects investment decision making because it can categorize investors who have different risk tolerance. Rational investors certainly expect certain returns with smaller levels of risk or expect high returns with certain risks. Which investment is chosen and the amount of funds invested is strongly influenced by investor tolerance for risk (risk tolerance), namely the attitude to the risk to be faced, whether investors like risk (risk seekers), avoiding risk (risk averter), or ignoring risk (risk indifference) Bailey and Kinerson [13] found that risk tolerance is a very strong predictor in investment decision making.

The third factor is the objective factor that has an influence on investment decisions. An objective factor is something that an investor wants to achieve in his investment [14]. The objective factor looks at the interests of investors in investing whether the investor wants to increase his wealth, maintain liquidity, or to minimize risk by diversifying. Research conducted by Manley and Glissmann [15] shows that objective factors influence stock investment, one of which is the presence of dividends. Basically, investment is a way to create and increase the value of wealth [16]. By considering the appropriate level of risk, the investor has the opportunity to get a higher long-term return. However, the existence of risk can also reduce the value of investment. In addition, Kapoor [17] also stated that capital gains and capital appreciation are important in investing. The fourth factor is the source of information. According to Chong et al., [18], investment decisions usually depend on the source of information sought and collected by investors.

The fifth factor is the market factor that influences investment decision making. Perera and Kulendran [19] said that market volatility has a great potential to affect stock performance 
because with fluctuating market conditions can cause stock prices to rise or fall so this can be a consideration for investors in investing in stocks. Market factors are also an indicator to look at performance by looking at all stocks or looking at stocks specifically because it can give signals to investors about future stock movements so that investors can see the development of investments to be taken.

The sixth factor is the company factor. Companies with good performance will attract more investors to invest in the company compared to companies that perform poorly. Companies with poor performance will make investors fear the risks they will bear in the future. The last factor is the stock fundamental factor Sharma and Sharma [20] show that investors value a company based on fundamental analysis. In addition, according to Albadvi et al., [21] fundamental analysis includes audit reports, financial statements, management expertise, and stock returns. The high stock returns given by the company, then investors will be interested in investing in these shares.

This study uses a population of financial management students in Surabaya, Indonesia. The chosen universities are Petra Christian University with 308 people, Surabaya University with 92 people, Widya Mandala Catholic University with 54 people, and Perbanas STIE with 134 people. The sample selection from the four universities because the university is a leading private university in Surabaya, has almost the same economic standards and has a financial management program. The sample of this study is active financial management students who have taken tertiary education at Petra Christian University, Surabaya University, Widya Mandala University, and STIE Perbanas and took semester four or more because the average tertiary institution entering a concentration in finance starts from the fourth semester.

Based on a pre-survey conducted on financial management students in Surabaya, from 80 students there were $39.1 \%$ of students who chose short-term capital gains as an objective factor in investing in shares. From the information source factor, $47.8 \%$ of students choose the internet as a source of information in investing in shares. On market factors, $65.2 \%$ of students look at the stock market performance in choosing investments. Meanwhile, on the company's factor as many as $47.4 \%$ of students see the company's reputation in choosing shares. For stock fundamental factors, $52.6 \%$ of students look at the price per share in investing in shares.

In addition, the selection of students in Surabaya because East Java is the third highest ranked province with 34 investors from 34 provinces in Indonesia after West Java with 144 766 investors. Of this number around 34514 investors reside in Surabaya or the largest in the province of East Java where $49 \%$ are local investors and the rest are foreign investors. As many as $30 \%$ of local investors are investors with an age group between $17 \mathrm{yr}$ to $30 \mathrm{yr}$ [22].

\section{Literature review}

These investments are generally found in the banking world and also in the money market, which in Indonesia is known as the Indonesia Stock Exchange. According to [23], financial instruments traded in the Indonesian Capital Market includes stocks, bonds, mutual funds, exchange traded fund (ETF), and derivatives. In making investment decisions, many factors are considered by investors. According to IDX [11], stock investment decisions are influenced by several factors, namely demographic factors, risk tolerance, objective factors, information source factors, market factors, company factors, and stock fundamental factors. 


\subsection{Demographics}

The influence of investor demographics needs to be considered, because in investment decision making, investors often involve more than one individual. Individuals who have a variety of different knowledge, expertise, and experience can be involved throughout the investment process, from planning, monitoring, to coordinating investment plans. Some demographic variables in this study include: age, income and gender. Based on [24], income is any additional economic capability received or obtained which is used for consumption or adding wealth. Investors are not only occupied by men, but women as well. In general, men are more overconfident than women. Therefore, men are more willing to take risks than women, in other words the behavior of male financiers tends to be risk seekers while the behavior of female financiers tends to be risk averter.

\subsection{Risk tolerance}

Risk tolerance is an acceptable level of ability to take an investment risk. Every investor has a difference in tolerance level. According to Abdul [25], when it is associated with investor preferences for risk, investors are divided into three, first is investors who like risk (risk seekers), meaning that investors who are faced with two investment choices that provide the same return with different risks, then investors will take higher risks. Usually this type of investor is aggressive and speculative in making investment decisions because they know that the relationship of return and risk is positive. The second type is risk neutral investors, meaning investors who will ask for the same increase in return for each increase in risk. This type of investor is generally quite flexible and prudent in making investment decisions. Third is investors who do not like risk or avoid risk (risk averter), meaning that investors who are faced with two investment choices that provide the same return with different risks, then he will prefer to take investments with lower risk.

\subsection{Objectives}

Objectives in investment are something that is expected and achieved by investors [14]. Investments in the capital market can be done by investors for three basic objectives, namely maximizing wealth, maintaining liquidity, and minimizing risk. In this study, stock objectives have four indicators namely short-term capital gains, long-term capital appreciation, dividends, and minimizing risk [11]. The first indicator is the short-term capital gains which are the benefits obtained when stock prices increase. This advantage can be realized when investors sell their shares [26]. The third indicator is dividend which is the payment received as a result of investment from shares. This payment is made to shareholders according to the schedule set by the company [26]. The last indicator is diversification that can minimizing risk.

\subsection{Information sources}

Mirshekary and Saudagarah [27] examine how investors use information contained in financial statements and examine the importance of various sources of information in making investment decisions. Based on research conducted, information from financial statements is the most influential source of information in investment decisions and then recommendations from friends, financial consultants, and others. Akhtar, Hunjra, and Rehman [28] revealed that the flow of information such as decisions made by the government, news in the media, and so on caused share prices to rise or fall. Due to the behavior of the stock market and new information, stock investors will make a decision for their investment. There are five indicators that support information source factors, namely 
the recommendation of family and friends, recommendations of financial consultants, magazines or newspapers, annual reports, and computers or the internet [11].

\subsection{Market}

There are two indicators that support market factors, namely the performance of the stock market and the performance of other markets such as the money market, the gold market, and others. Market conditions are a reflection of investors' expectations of future economic conditions. The movement of stock prices and indices is what will give an idea of stock trends, sectors and the economy as a whole [11].

\subsection{Firm}

There are two indicators that support firm variables, namely firm size and firm reputation. Firm size is a reflection of market capitalization, book value and corporate profits [11]. The basis for company measurement is that large scale companies have a market value of more than IDR $5 \times 10^{12}$, medium companies that have a stock value of between IDR $1 \times 10^{12}$ to IDR $5 \times 10^{12}$, and small companies have a stock value of less than IDR $1 \times 10^{12}$ [29]. Meanwhile, the firm's reputation is an evaluation of the overall stakeholders of the company from time to time.

\subsection{Fundamental}

Fundamental analysis is an analysis based on the intrinsic value of a security or value that can be estimated by investors. This value is a variable that underlies a company. Research conducted by Geetha and Vimala [11] uses seven indicators in fundamentals, namely share price per share, earnings per share (EPS), which is the amount of earnings per share outstanding from company stock, price earning ratio $(\mathrm{P} / \mathrm{E})$, which is the ratio of market price per share to net income per share, dividend payout ratio, which is the ratio that shows the percentage of each profit earned and distributed to shareholders in cash, debt to equity ratio, the ratio used to measure the level of debt use to the total shareholder's equity owned by the company, return on equity (ROE), the profit received by the company from the results of investments made by investors, and stock price volatility from the previous period. This is considered a rational attitude towards investors.

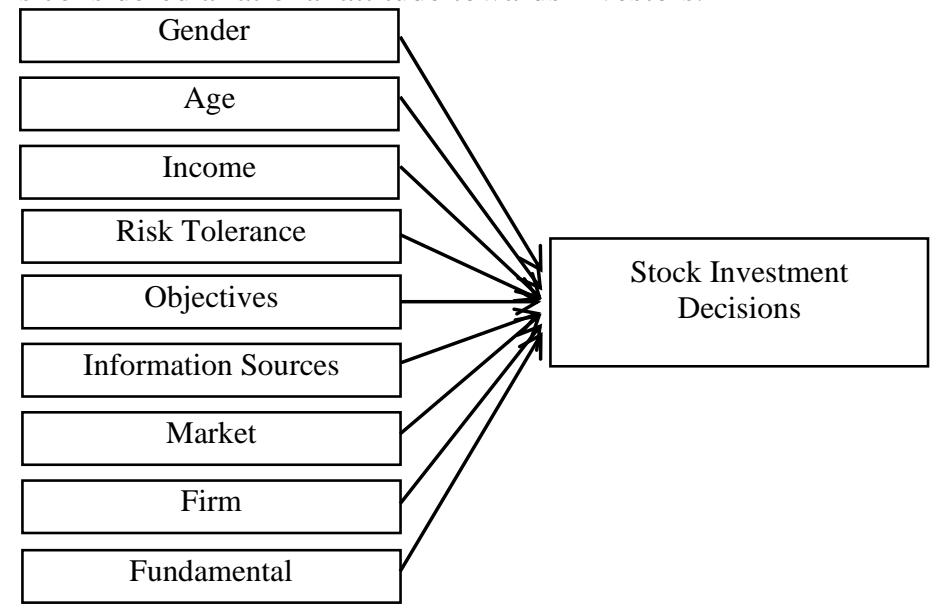

Figure 1. Theoritical framework 


\section{Research methods}

The research data was obtained through a questionnaire with a purposive sampling technique. Criteria for respondents used financial management active students who took semester four or more, and active financial management students who took tertiary education in Surabaya. This research was conducted on 238 financial management students in Surabaya. Sample data will be processed using SPSS.

\section{Analysis and discussion}

Each indicator of this research variable has a validity $<0.05$ so that it can be declared valid. In addition, the variables used are reliable because they have a critical value> 0.06 . In addition, the R-Square in this study amounted to 0.381 . This value indicates that stock investment decisions can be explained by factors of gender, income, age, risk tolerance, objective factors, information source factors, market factors, company factors, and fundamental factors by $38.1 \%$, while the remaining $61.9 \%$ are influenced by other factors.

The hypothesis is accepted if the significance $<0.05$. Based on Table 2 it can be seen that gender, income, risk tolerance, objective factors, information source factors, company factors, and fundamental factors significantly influence stock investment decisions. Meanwhile, age and market factors do not significantly influence stock investment decisions.

Table 1. Hypothesis Testing Results

\begin{tabular}{cc}
\hline Variable & t-statistic svalue \\
\hline $\mathrm{GE} \rightarrow$ SID & 0.002 \\
$\mathrm{AG} \rightarrow$ SID & 0.495 \\
$\mathrm{IC} \rightarrow \mathrm{SID}$ & 0.032 \\
$\mathrm{RT} \rightarrow \mathrm{SID}$ & 0.003 \\
$\mathrm{OB} \rightarrow \mathrm{SID}$ & 0.000 \\
$\mathrm{IS} \rightarrow \mathrm{SID}$ & 0.016 \\
$\mathrm{MK} \rightarrow \mathrm{SID}$ & 0.077 \\
$\mathrm{FI} \rightarrow$ SID & 0.002 \\
$\mathrm{FUN} \rightarrow$ SID & 0.34 \\
\hline
\end{tabular}

\subsection{The effect of demographic factors on stock investment decisions}

Gender has a significant effect on stock investment, it can be seen that students who have more stock investment are 94 male students and 62 female students. The small number of women in stock investments is because women are more careful so they tend to avoid investments that have a high degree of uncertainty.

Income has a significant effect on stock investment decisions, which means that investors will increase purchases of shares in line with increasing income. In this study, in general it can be seen that the number of students who have stock investments increases with increasing income so that students with large incomes will be braver to invest in stock investments with the hope of getting high returns. It can be seen that students with income < IDR 1500 000, there are 36 people who invest in shares, income between IDR 1500001 - IDR 2500 000, there are 46 people who invest in shares, income between IDR 2500001 - IDR 3500000 there are 36 people who invest shares, and income > IDR 3500000 there are 38 people who invest in shares.

Age does not have a significant effect on stock investment decisions because respondents in this study have an age range close to the age range between $18 \mathrm{yr}$ to $22 \mathrm{yr}$ so that there are no gaps in age, thought or behavior. Almost equal age does not have a 
significant impact on stock investment decisions. This shows that students aged $18 \mathrm{yr}$ to $22 \mathrm{yr}$ have the same considerations in making investment decisions. They use the information and knowledge they have when making investments and also they will be more selective and be careful about the risks and returns they get.

\subsection{The effect of risk tolerance on stock investment decisions}

Risk tolerance has a significant effect on stock investment decisions. This is the same as the results studied by Bailey and Kinerson [13]. Conservative investors prefer to invest in blue chip stocks because they can have high liquidity, although this stock may one day go down but it will definitely go up again [30]. In addition, neutral investors can choose to invest in blue chip stocks and second layer shares. Finally, aggressive investors are braver with shares with a small capitalization market because they can provide large growth and large profits, even though they also have a large risk.

From the results of this study it can be seen that many conservative respondents have a stock investment. This is because respondents from the research are still categorized as students so they can be referred to as novice investors. In addition, this conservative student will choose to invest in stocks with large market capitalization such as blue chip stocks because of the stable price movement of shares and good fundamentals.

\subsection{The effect of objectives on stock investment decisions}

The objective factor in investing is the investor's goal which refers to what the investor wants to achieve with his investment. In this study, objective factors significantly influence stock investment decisions. The indicators contained in this study are short-term capital gains, long-term capital appreciation, dividends, and risk minimization. A significant indicator in the objective factor is the long-term capital appreciation indicator. Long-term capital appreciation is the goal of investors who invest in the long term so that the students in this study who are mostly conservative invest with a long-term orientation so that students are more concerned with the benefits received in the future rather than getting profits in the short term. It can be concluded that the purpose of students investing to be used as funds in the future for example for children's education costs, pensions, and others. Students who are concerned with long-term capital appreciation in their objective investment factors do not need to worry about stock fluctuations that occur every day because the increase in value of the shares occurs passively and gradually, but in addition students must continue to pay attention to company fundamentals that can affect long-term growth in investment.

\subsection{The effect of information sources on stock investment decisions}

Information sources significantly influence stock investment decisions so that in this research in making stock investment decisions students will look for information about the selected stocks from various sources before making investment decisions. The indicators in this study are recommendations from family and friends, recommendations from financial consultants, financial statements of companies, and information from the internet. A significant indicator in terms of information sources is the company's financial statements. Students in this study see the financial statements as a source of information in stock investments because the company's financial statements can be used as a source to see how the performance of a company. For investors and potential investors, financial statements can make them sure or not to invest in the company. This is because the information in the financial statements can provide an analysis of how companies will develop funds from these investments to then be able to provide benefits for investors. 


\subsection{The effect of market on stock investment decisions}

In this study, it was found that the market did not significantly influence stock investment decision making. The indicators in this study are stock market conditions and other market conditions (money market, gold market, etc.). Student investors in this study did not pay attention to the condition of the stock market or other markets in investing in shares due to speculative market conditions so that investors are more careful in investing and do not follow market conditions but pay more attention to corporate fundamentals. In addition, in investing students do not use perceptions and predictions on market conditions, but students look more at information from data contained in the company's financial statements.

\subsection{The effect of firm on stock investment decisions}

The firm has a significant influence on stock investment decisions. The indicators in this study are company size and company reputation. The indicator which influences company factor is company size. Small-sized companies are less profitable compared to large companies because small companies only have supporting factors and production with a limited amount so that they have a greater risk than large companies. Student investors in this study looked at the size of the company in choosing investment because the large size of the company showed that the company was developing so that the value of the company would increase and this large company also had a small level of risk. Students in this study also have a conservative risk tolerance so that they choose shares in terms of the company because shares from large companies are relatively safer than small companies and have stable growth and good fundamentals.

\subsection{The effect of fundamental factors on stock investment decisions}

Fundamental influences significantly on stock investment decisions so in this study students conduct fundamental analysis before making decisions in stock investing. Fundamental analysis in stock investment has a strong foundation that is of intrinsic value that can be determined through an analysis of the condition of the company at present and in the future. Intrinsic value can also provide information to respondents about the profit (return) that will be generated on the stock. Fundamental analysis is also one of the easiest ways to value a company. The main objective in fundamental analysis is to see the value of the company at this time.

The indicators in this study are share price, earnings per share, price-earnings ratio, dividend payout ratio, debt to equity ratio, return on equity, and stock price volatility in the previous period. A significant indicator in fundamental factors is the price of shares per sheet. In this study shows that the share price per share has an influence in stock investment because most students have limited funds and the economic level of students who are studying in college must be different. There are students who are less able, students who live abroad and have to bear their own lives so that the stock price for students is something that needs to be considered in investing in shares. A low stock price also has a positive effect on the company because it can attract investors to invest because when the price of a stock is low the investor will invest in the stock and can sell it back when the price rises.

\section{Conclusions}

Based on the results of the analysis and discussion, the conclusions of this study are gender, income, risk tolerance, objective factors, information source factors, company factors, and fundamental factors that significantly influence stock investment decisions. Meanwhile, age 
and market factors do not significantly influence stock investment decisions. Further research can use other variables such as financial literacy, financial behavior, financial knowledge, and experience. For students, in order to consider the factors needed before investing in shares.

\section{References}

1. CMA, Investment. Kingdom of Saudi Arabia: Capital Market Authority (2019). p. 1-16. https://cma.org.sa/en/Awareness/Publications/booklets/Booklet_1.pdf

2. H.B. Mayo, Investments: An Introduction, South Western: Thomson (2014). https://trove.nla.gov.au/work/7589452

3. BKPM, Realisasi Penanaman Modal PMDN-PMA [Realization of PMDN-PMA Investment]. Jakarta: BKPM (2018). p. 1-38. [in Bahasa Indonesia]. https://www.bkpm.go.id/images/uploads/file_siaran_pers/Paparan_Indonesia_TW_IV _-2017_Kepala.pdf

4. L. Hendra, 30.000 Mahasiswa Jadi Investor Saham, [30,000 Students Become Stock Investors], [Online] from http://market.bisnis.com/read/20170417/190/645628/30.000-mahasiswa-jadi-investor-

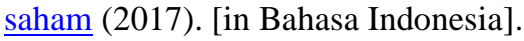

5. N.M. Rochmi, Gaet Investor Kecil, Bursa Akan Turunkan Satuan Lot Saham. [Attract Small Investors, The Exchange Will Reduce Unit Lot of Shares]. [Online] from https://beritagar.id/index.php/artikel/berita/gaet-investor-kecil-bursa-akan-turunkansatuan-lot-saham (2018). [in Bahasa Indonesia].

6. Tribunnews, RELI Mendorong Semakin Banyak Investor Muda di Pasar Modal. [RELI Encourages More and More Young Investors in the Capital Market]. [Online] from http://www.tribunnews.com/bisnis/2018/11/23/reli-mendorong-semakin-banyakinvestor-muda-di-pasar-modal?page $=2$ (2017). [in Bahasa Indonesia].

7. Detikfinance, Genjot Jumlah Investor, BEI Sasar Kalangan Mahasiswa. [Boost the Number of Investors, IDX Targets Students]. [Online] from https://finance.detik.com/bursa-dan-valas/d-2357067/genjot-jumlah-investor-beisasar-kalangan-mahasiswa (2013). [in Bahasa Indonesia].

8. CNN Indonesia, BEI Klaim Sukses Gaet 5 ribu Pemain Saham Baru, [IDX Claims Successfully Attracts 5 thousand New Stock Players], [Online] from https://www.cnnindonesia.com/ekonomi/20160107141857-78-102846/bei-klaimsukses-gaet-5-ribu-pemain-saham-baru (2016). [in Bahasa Indonesia].

9. Office of Investor Education and Advocacy, Saving and Investing for Students, USA: U.S. Securities and Exchange Commission (2019). https://www.sec.gov/investor/pubs/savings-investing-for-students.pdf

10. I.M. Candiasa, N.T. Herawati, N. Suharsono, I. K. Yadnyana, JPEKA, 2,2:115128(2018). [in Bahasa Indonesia]. https://journal.unesa.ac.id/index.php/jpeka/article/view/3056

11. N.A. Heshmat, International Journal of Commerce and Management, 22,1:7590(2012). https://www.emeraldinsight.com/doi/full/10.1108/10569211211204528

12. S.N. Geetha, K. Vimala, Procedia Economics and Finance, 11:360-374(2014). https://www.sciencedirect.com/science/article/pii/S2212567114002044

13. J.J. Bailey, C. Kinerson, Association for Financial Counseling and Planning Education, 16,1:23-28(2015). https://www.afcpe.org/wpcontent/uploads/2018/10/vol1613.pdf

14. H. Bulus, N.R. Ikeobi, S.K. Msheliza, Journal of Poverty, Investment and Development, 40,1:82-87(2017). https://iiste.org/Journals/index.php/JPID/article/view/40482 
15. R. Manley, C.M. Glissmann, Financial Analysts Journal, 64,3:17-29(2008).

https://www.jstor.org/stable/pdf/40390213

16. Vanguard, Investment Fundamentals An Introduction to The Basic Concepts of Investing, UK: Vanguard Asset Management, Limited. (2015). p. 1-36.

https://www.vanguard.co.uk/documents/portal/literature/investment-fundamentalsguide.pdf

17. N. Kapoor, International Journal of Research (IJR), 1,10:1364-1370(2014), https://journals.pen2print.org/index.php/ijr/article/view/975/921

18. L.L. Chong, M.T.I. Khan, S.H. Tan, Managerial Finance, 43,8:928-947(2017). https://www.emeraldinsight.com/doi/abs/10.1108/MF-08-2016-0232

19. W. Perera, N. Kulendran, Corporate Ownership \& Control, 13,3:502-517(2016). http://dr.lib.sjp.ac.lk/bitstream/handle/123456789/5851/SHORT-

RUN\%20UNDERPRICING\%20AND\%20ITS\%20DETERMINANTS;\%20EVIDEN CE\%20FROM\%20AUSTRALIAN\%20IPOS.pdf?sequence $=1$

20. M. Sharma, P. Sharma, Vision: The Journal of Business Perspective, 13,3:3140(2009). https://journals.sagepub.com/doi/abs/10.1177/097226290901300303

21. A. Albadvi, S.K. Chaharsooghi, A. Esfahanipour, European Journal of Operational Research, 177,2:673-683(2007).

https://www.sciencedirect.com/science/article/pii/S0377221705009331

22. L. Hakim, Investor dan Transaksi Pasar Modal di Jatim Terus Meningkat, [Investors and Capital Market Transactions in East Java Continue to Increase]. [Online] from https://ekbis.sindonews.com/read/1284647/32/investor-dan-transaksi-pasar-modal-dijatim-terus-meningkat-1519386865 (2018). [in Bahasa Indonesia].

23. Indonesia Stock Exchange. Introduction to Capital Market. [Online] from https://www.idx.co.id/en-us/investor/introduction-to-capital-market/ (n.d).

24. BKPB. Undang-Undang Republik Indonesia Nomor 17 Tahun 2000 Tentang Perubahan Ketiga Atas Undang-Undang No. 7 Tahun 1983 Tentang Pajak Penghasilan, Jakarta, Lembaga Manajemen Formasi, [Law of the Republic of Indonesia Number 17 of 2000 concerning the Third Amendment to Law No. 7 of 1983 concerning Income Taxes, Jakarta, Institute for Formation Management]. Law of the Republic of Indonesia (2001). p. 1-32. [in Bahasa Indonesia]. http://www.bpkp.go.id/uu/filedownload/2/43/356.bpkp

25. H. Abdul, Analisis Investasi, [Investment Analysis], Jakarta: Salemba Empat (2005).

[in Bahasa Indonesia].

https://scholar.google.co.id/scholar?hl=en\&as_sdt=0,5\&cluster $=16014867663296096$ $\underline{712}$

26. M. Mobius, Mutual Funds: An Introduction to the Core Concepts. USA: John Wiley \& Sons (2007).

https://books.google.co.id/books?hl=en\&lr=\&id=OCAXVP6Jp YC\&o

27. S. Mirshekary, S. Saudagarah, Journal of International Accounting, Auditing and Taxation, 14,2:33-54(2005). https://www.sciencedirect.com/science/article/pii/S1061951805000030

28. M.N. Akhtar, A.I. Hunjra, K. Rehman, Actual Problems of Economics, 11,11:356363(2011). https://www.researchgate.net/publication/216520371

29. I.N. Rahmati, S. Mutmainah, Haryanto, MAKSI, 7,1:87-103(2007). [in Bahasa Indonesia].

http://eprints.undip.ac.id/35132/1/JMAKSI_Jan_2007_06_Ita_Nur_Rahmawati.pdf

30. H.A. Putranto, Journal of Economics, 1,1:1-20(2016). [in Bahasa Indonesia]. http://jurnalfebi.uinsby.ac.id/index.php/oje/article/view/19 